\title{
Repudiated Compromise After Breach
}

\author{
Mary Lou Serafine
}

The repudiated compromise arises when one party to a contract threatens to or does actually breach some term of a contract and, rather than take the problem to court, the parties agree to a compromise. Perhaps a buyer agrees to a new, higher price or to tolerate a seller's delay in performance. After the would-be breacher has performed, however, the other party repudiates the compromise by refusing to perform its revised obligation (e.g., refusing to pay the higher price) or by suing for damages under the original contract (e.g., suing for the delay). In such a case the court must decide whether to uphold the original contract, which would have been breached by one party, or to uphold the subsequent compromise, which is now repudiated by the other. The parties come to court having made two agreements for different results, one agreement seeming to have priority because it was first, the other so seeming because it is the most recent. Two historic and widely cited cases follow:

Case 1: Ship with a crew of ten sailors embarks on an expedition, wages for each sailor having been fixed in advance. Enroute, two sailors desert. The captain offers to disburse wages of these two among the remaining eight if they will continue despite reduced crew size. Crew agrees. On completion of the expedition, crew is paid only the original, not higher, wage. One sailor sues. Held, judgment for the captain and employer on grounds that the sailors had a pre-existing duty to complete the voyage and that new consideration for the second agreement was absent. $^{1}$

Case 2: Ship's crew is hired in San Francisco for a fishing expedition, the wages of each crew member fixed in advance. Once off the coast of Alaska, the crew refuses to continue unless the employer doubles their wages. The employer agrees. On completion of the expedition, crew is paid only the original, not higher, wage. Crew sues. Held, judgment for the employer on grounds of pre-existing duty in the crew and absence of new consideration for the second agreement. ${ }^{2}$

Nearly a hundred years apart, the courts reached identical holdings under identical doctrine, appearing to disregard important differences between the two

1. Stilk v. Myrick, 170 Eng. Rep. 1168 (K.B. 1809).

2. Alaska Packers' Ass'n v. Domenico, 117 F. 99 (9th Cir. 1902). 
cases. The crew in Case 1 shoulders a burden (sailing with fewer crew) for which they did not originally contract, ultimately performing more work for the same pay; the crew in Case 2 "holds up" its employer, when the employer has no other options, in order to extract more pay for the same work that was originally contracted. ${ }^{3}$ Conventional doctrine, though, provides no means of distinguishing these quite distinct cases. Rather, courts have inconsistently upheld both contracts and compromises when repudiation of a compromise follows upon breach of the original agreement. ${ }^{4}$

Solutions to the problem of repudiated compromise have been meager. One solution is the state of mind theory, ${ }^{5}$ in which the parties' respective states of mind at the time of the compromise are dispositive: if voluntary, then the compromise is upheld; if not the contract is upheld. Endorsed by some courts, ${ }^{6}$ the state of mind theory nevertheless runs afoul of certain problems, ${ }^{7}$ and other courts have explicitly disavowed it. ${ }^{8}$

This Note proposes a rule of decision for resolving cases of repudiated compromise. The rule diverges from traditional doctrine, especially the doctrine of pre-existing duty and consideration, and also avoids disposition based on states of mind. In brief the rule is that, where a compromise follows a breach that is caused by changed conditions, the compromise is upheld if it is consistent with the risk allocation implied by or explicit in the original contract; if the compromise is not consistent with that allocation, then the contract is upheld. Alternatively, where a compromise follows a breach not caused by changed conditions, the contract is always upheld.

This rule preserves the ends for which contracts are designed. ${ }^{9}$ These ends are, first, that wealth- or value-enhancing exchanges should occur, and second that, under a contract, such exchanges are facilitated because the parties need not perform their obligations simultaneously. That is, contracts allow a party to rely upon its partner's future performance. As discussed infra, these ends are achieved only when a stable risk allocation is maintained across both the contract and subsequent compromise. Thus, the proposed rule ensures a stable risk allocation when some unanticipated risk or change of conditions arises.

3. Under the theory proposed herein, these two cases would be decided differently. See infra discussion at Section III

4. See infra Part I for discussion of courts' inconsistency.

5. See Hillman, Policing Contract Modifications Under the UCC: Good Faith and the Doctrine of Economic Duress, 64 IowA L. REV. 849 (1979).

6. Reiver v. Murdoch \& Walsh, 625 F. Supp. 998, 1016 (D. Del. 1985); Alexander v. Standard Oil Co., 97 Ill. App. 3d 809, 814, 423 N.E.2d 578, 583 (11l. App. Ct. 1981).

7. One problem is that it requires the court to determine what, in fact, were the parties' states of mind at the time of the compromise, and this is likely to be difficult. Another is that, to the degree that judicial outcomes create incentives for future behavior, a state of mind holding warns parties that, if they want to win later in court, they should at least appear to be under duress, even if they are not. Such holdings might provide incentives for the mere appearance of the judicially approved state of mind and thereby distort genuine negotiation.

8. Selmer Co. v. Blakeslee-Midwest Co., 704 F.2d 924, 927 (7th Cir. 1983) (Posner, J.).

9. See infra Part II for discussion of rationale. 
Part I of this Note demonstrates the need for the rule by showing that courts have been inconsistent in treating repudiated compromises, in both older and recent cases. ${ }^{10}$ Part II describes and provides a rationale for the rule, and Part III applies it to sample cases.

\section{CASEs AND EXTANT Doctrine}

Historically courts have been inconsistent in their disposition of breached compromises, employing certain doctrines to uphold original contracts and alternative ones to uphold compromises. For example, the courts have employed the doctrines of pre-existing duty, absence of new consideration, ${ }^{11}$ economic duress, ${ }^{12}$ and unequal bargaining power ${ }^{13}$ to uphold original contracts and set aside compromises. Just as often the courts have applied the doctrines of frustration (or impossibility) ${ }^{14}$ and of fairness to reach the opposite holding, preserving the compromise and voiding the contract. In two illustrative cases, ${ }^{15}$ the contract or compromise was upheld under a particular doctrine at trial, then set aside under an entirely different doctrine on appeal. In short, courts have been unable to resolve the dilemma of parties who make conflicting claims not about the same agreement (as in the single contract case) but about two different agreements that ostensibly govern the same transaction. Examples of historic and recent cases follow.

10. The problem of repudiated compromises is very old, and the structure of the underlying fact patterns leading to the problem has remained remarkably constant. The classic duress pattern, for example, has spanned more than a century of American litigation: victim of breach, under duress, signs waiver releasing his adversary from liability for a wrongful act. See, e.g., International Paper Co. v. Whilden, 469 So. $2 \mathrm{~d}$ 560 (Ala. 1985); Hackley v. Headley, 45 Mich. 569, 8 N.W. 511 (1881); Goldbard v. Empire State Mut. Life Ins. Co., 5 A.D.2d 230, 171 N.Y.S.2d 194 (N.Y. App. Div. 1958).

11. The doctrine of consideration has itself given rise to inconsistency. Compare Spencer v. McLean, 20 Ind. App. 626, 50 N.E. 769 (1898) (promise made to induce another to do act he is already legally bound to do is without consideration) with Wescott v. Mitchel, $95 \mathrm{Me} .377,50 \mathrm{~A} .21$ (1901) (mere agreement to perform existing contract obligation is valid consideration for new promise by other party).

12. See Dalzell, Duress by Economic Pressure, in THE ECONOMics OF CONTRACT LAW (A. Kronman \& R. Posner eds. 1979) 67-72; Dawson, Economic Duress-An Essay in Perspective, 45 MICH. L. REv. 253 (1947); Hale, Bargaining, Duress, and Economic Liberty, 43 COLUM. L. REV. 603 (1943); Hillman, Policing Contract Modifications Under the UCC: Good Faith and the Doctrine of Economic Duress, 64 IOWA L. REV. 849 (1979); Mather, Contract Modification Under Duress, 33 S.C.L. REV. 615 (1982); Muris, Opportunistic Behavior and the Law of Contracts, 65 MINN. L. REV. 521 (1981); Narasimhan, Modification: The Self-Help Specific Performance Remedy, 97 Y ALE L.J. 61 (1987); Robison, Enforcing Extorted Contract Modifications, 68 IOWA L. REV. 699 (1983). See generally Epstein, Unconscionability: A Critical Reapprais$a l$, in THE ECONOMICS OF CONTRACT LAW 93 (A. Kronman \& R. Posner eds. 1979); Schwartz, A Reexamination of Nonsubstantive Unconscionability, 63 VA. L. REV. 1053 (1979).

13. See Trebilcock, The Doctrine of Inequality of Bargaining Power, in THE ECONOMICS OF CONTRACT LAW 78 (A. Kronman \& R. Posner eds. 1979).

14. See Posner \& Rosenfield, Impossibility and Related Doctrines in Contract Law, in THE ECONOMICs OF CONTRACT LAW 122 (A. Kronman \& R. Posner eds 1979). (1974).

15. Recker v. Gustafson, 279 N.W.2d 744 (Iowa 1979); Angel v. Murray, 113 R.I. 482, 322 A.2d 630 


\section{A. Compromises Upheld}

In the classic case of Goebel v. Linn, ${ }^{16}$ the original contract called for an ice company to supply a brewer with ice at $\$ 1.75$ per ton or $\$ 2.00$ per ton if the ice crop was short. Because of an especially mild winter and short crop, the ice company threatened breach but offered a compromise at a higher price. The brewer, whose beer would otherwise spoil, agreed to the ice company's demand for $\$ 3.50$ per ton. Later, the brewer refused to complete payments, and the ice company sued. The court held the brewer to the compromise at the higher price. It reasoned that the ice which was consideration for payment under the original contract was equally consideration for the compromise because it was owned by the ice company and subsequently bought by the brewer. The ice company's demand for a higher price was motivated by unexpected conditions (the mild winter) and not by a desire to take advantage of the brewer's need for ice. Thus, the brewer did not succumb to duress or extortion. Rather, the brewer might have stood upon its contractual rights and sued under the original contract at the time of the breach; that it chose not to do so, for reasons it must have deemed sufficient, shows that it entered voluntarily into the compromise. ${ }^{17}$

The Goebel court explicitly relied on the doctrine of impossibility or frustration (i.e., the ice company's performance of the original contract was frustrated by the mild winter), and the court minimized the issues of new consideration for the compromise and the brewer's economic duress. The court implicitly relied on the assumption of equal bargaining power between parties, for it noted that both parties had full knowledge of the facts and that the compromise prevented both businesses from coming to ruin on account of a mild winter.

The Goebel court relied for authority on Moore v. Detroit Locomotive Works, ${ }^{18}$ which employed the same doctrines. In Moore, the manufacturer of a locomotive engine was long delayed in delivery, causing business losses to the buyer. When the manufacturer was finally ready to deliver, it refused to do so without first receiving from the buyer a waiver which released the manufacturer from all liability for the delay. In favoring the manufacturer and upholding this compromise, the court held that the manufacturer's promise not to breach the original contract (through nondelivery) was sufficient consideration for the waiver demanded in the compromise.

A modern case that parallels Goebel and Moore is Angel v. Murray. ${ }^{19}$ Here a refuse hauler and a municipality, after reaching a contract for refuse collection, later agreed to a compromise that required the city to pay the refuse hauler

\footnotetext{
16. 47 Mich. 489 , 11 N.W. 284 (1882).

17. Id. at 493,11 N.W. at 285 .

18. 14 Mich. 266 (sic) (1866).

19. 113 R.I. 482 , 322 A.2d 630 (1974).
} 
an additional $\$ 10,000$ per year for two years. Changed conditions allegedly justified these higher payments. Housing in the city had increased by 400 units, whereas the original contract had been predicated on an average annual increase of only twenty to twenty-five units. The trial judge had ordered the refuse hauler to repay the city the $\$ 20,000$ specified in the compromise, upholding the original contract under the doctrines of pre-existing duty and the absence of new consideration. ${ }^{20}$ The refuse hauler, the trial court had said, was already obligated to dispose of the city's refuse, and so the second agreement (compromise) which was without new benefit to the city, was void. On appeal the Supreme Court of Rhode Island reversed, setting aside the original contract and upholding the compromise under the fairness doctrine. ${ }^{21}$ Although acknowledging the pre-existing duty rule (and the confusion in this area of the law) the supreme court reasoned that a fair and equitable compromise, arrived at voluntarily, should be upheld even when new consideration is not involved. Employment of the fairness doctrine here rested on the doctrine of frustration by changed conditions: housing had increased.22

The above cases show that the doctrines of fairness, consideration, and impossibility or frustration by changed conditions have been employed to uphold compromises. In every case, the court set aside the original contract and granted judgment in favor of the breacher or would-be breacher of the original contract.

\section{B. Compromises Set Aside}

Alaska Packers' Association v. Domenico ${ }^{23}$ is one of the most cited cases in which a compromise was set aside. As described above as Case 2, a crew of sailor-fishermen agreed to complete a fishing expedition, but once off the coast of Alaska they refused to continue unless their employer doubled their pay. Lacking an alternative source of labor, the employer agreed. On completion of the trip, however, the employer paid the original, lower wage. In favoring the employer and setting aside the compromise, the circuit court reasoned that the doctrine of pre-existing duty, coupled with the absence of new consideration and the coercion or duress endured by the employer, dictated that the original contract should be upheld. ${ }^{24}$

The identical doctrine had been used earlier in two cases that are superficially similar to Alaska Packers. In Reynolds v. Nugent, ${ }^{25}$ a town offered to

20. See id. at 632 .

21. Id. at 636.

22. Note that parties to the contract here were not in disagreement about the fairness of the compromise; both supported it. The suit was initiated by citizens of the city who objected to the city's increased payments to the refuse hauler.

23. 117 F. 99 (9th Cir. 1902).

24. Id. at 102 .

25. 25 Ind. 328 (1865). 
pay a soldier $\$ 100$ for fighting on its behalf in the American Civil War. The mercenary accepted the offer, but just before being mustered in, he received an offer of $\$ 350$ to fight for another town. Thereupon the town with which he had originally contracted offered to match this offer and so increased its pay to $\$ 350$. Under this compromise, the soldier performed. After the war, the town paid him only $\$ 100$. The court ruled against the soldier and upheld the original contract under the doctrines of pre-existing duty and absence of consideration for the compromise. ${ }^{26}$

The case of Stilk v. Myrick, ${ }^{27}$ described as Case 1 above, is similar. Here a crew lost two members enroute, and their employer agreed to pay the remaining crew additional wages. At the completion of the trip, however, he paid only the original, lower wage, which was upheld by the court under the pre-existing duty doctrine. The sailors were already required, reasoned the court, to complete the expedition. ${ }^{28}$

It is arguable whether in Stilk (higher wage for crew reduced in size) or in Reynolds (higher wage for mercenary offered more by another town) the respective employers were also under economic duress. Certainly in Alaska Packers (higher wage for crew refusing to continue) it was not only the preexisting duty in the crew but also the economic duress of the employer which led the court to set aside the compromise.

A modern case of compromise set aside on grounds of economic duress is Austin Instrument, Inc. v. Loral Corp. ${ }^{29}$ Here a seller threatened breach by ceasing deliveries unless the buyer agreed to pay higher prices for goods already received and forthcoming. Because the buyer desperately needed the goods (having dependent contractual obligations to a third party) and could not obtain them elsewhere, the court held that he had agreed to the higher, compromise prices only under economic duress. Thus the compromise was set aside. ${ }^{30}$

Similarly, in Roth Steel Products. v. Sharon Steel Corp. ${ }^{31}$ buyers who were under contract had to accept price increases and delivery delays when the sellers threatened breach and the buyers were unable to obtain the material

26. Id. at 329-30.

27. 170 Eng. Rep. 1168 (K.B. 1809).

28. Id. at 1169.

29. 29 N.Y.2d 124, 272 N.E.2d 533, 324 N.Y.S.2d 22 (1971).

30. Part of the court's dilemma, of course, is determining whether the would-be victim of duress or breach should be excused for not having stood upon his legal rights earlier, bringing suit at the time of breach instead of yielding to a compromise and then repudiating it. In fact, in the early Radich case the Supreme Court held that plaintiff should have gone so far as to avoid transacting business with one who would put him under duress. When Radich tried to export his cotton, an officer of the Confederacy refused to issue the required permit except on exorbitant payment of cash or a giving over of half the goods. Radich paid exorbitantly, then sued. Held, judgment for defendant: plaintiff could have kept his cotton. Radich v. Hutchins, 95 U.S. 210 (1877). There are modern cases decided on the same reasoning. See Selmer Co. v. Blakeslee-Midwest Co., 704 F.2d 924, 928 (7th Cir. 1983) (victim of breach need not have compromised); Joyce v. Year Investments, Inc., 45 Ill. App. 2d 310, 196 N.E.2d 24 (1964) (duress does not exist when victim had choice to take legal action but instead entered into compromise).

31. 705 F.2d 134 (6th Cir. 1983). 
elsewhere. Finding that the sellers engaged in coercion (threatening not to sell further to the buyer), the court set aside the compromise with higher prices. The case was complicated, however, by the fact that the sellers demanded price increases at a time when market conditions had greatly escalated the price of steel (the good in question), and the supply could not be increased because the industry was operating at full production capacity. In dicta, the court indicated that such changes in market conditions would legitimately prompt a seller to seek a higher price, but seeking such with coercive conduct invalidated the resulting compromise. ${ }^{32}$

Recker v. Gustafson ${ }^{33}$ is a modern case of compromise set aside on the ground that there was no new consideration for it. Here the parties had a contract for the sale of land. The sellers sought a price increase of $\$ 10,000$ and to which the buyers agreed. The court held that where there is no rescission of the original contract, but only a modification of its terms, new consideration is necessary. Because there was no consideration for the second agreement, it was not binding. ${ }^{34}$

The above examples of compromises set aside show that the doctrines of duress, economic duress, pre-existing duty, and consideration may be used to uphold original contracts and thereby favor the party who was the victim of the original breach.

\section{Conclusion}

As we have seen, a court may employ any of a number of conflicting doctrines to reach its desired result in situations of repudiated compromise after breach. Using the doctrine of economic duress, for example, courts have set aside some compromises but not others. The courts in Alaska Packers, Austin Instrument, and Roth Steel found that evidence of economic duress will void a compromise, ${ }^{35}$ but the courts in Goebel ${ }^{36}$ and Moore ${ }^{37}$ upheld compromises even when the buyer agreed to them under conditions of economic duress.

Courts have also applied the doctrine of frustration inconsistently. The courts in Goebel and Angel allowed the changed conditions under which one party would perform (respectively, harvesting ice in a mild winter and collecting refuse at more homes) to set aside an original contract and replace it with

32. Id. at $147-48$.

33. 279 N.W.2d 744 (lowa 1979).

34. Compare Recker with Skinner v. Tober Foreign Motors, Inc., 345 Mass. 429,187 N.E.2d 669 (1963) (compromise set aside where sellers lowered buyer's installment payments, but later repudiated and sought replevin). In Skinner, the court held that modification of the terms of a contract needs no new consideration to be binding. Although the cases appear to conflict, a major difference between them is that, Skinner's sellers, unlike Recker's, voluntarily lowered rather than raised buyer's payments.

35. In Alaska Packers the employer had no other crew available to complete the fishing expedition; in Austin Instrument and Roth Steel the goods were needed for manufacturing other products under contract.

36. In Goebel the buyer needed ice to produce beer.

37. In Moore the buyer needed the locomotive engine to run a train line. 
a compromise. But prior to both these cases, the English common law, exemplified in Stilk, ${ }^{38}$ had not approved the frustration of a pre-existing duty by changed conditions giving rise to compromise. Not only changed conditions generally, but also changes in market conditions, have been viewed inconsistently by courts. In the case of Reynolds, the fact that the mercenary could better profit by fighting for another town was not seen to justify a breach and compromise, but the dicta of Roth Steel indicates the opposite: if a higherpaying buyer can be found, the seller would seemingly be justified in seeking the better profit.

The doctrine of consideration has also been applied inconsistently in upholding and setting aside repudiated compromises. The courts in Goebel, Moore, and Angel did not require new consideration for their respective compromises and so upheld them. On the contrary, several courts-Alaska Packers, Reynolds, Stilk, and Recker ${ }^{39}$-held that without consideration the compromise was void, and the parties kept to their original obligations.

Under inconsistent doctrines, then, courts have both upheld and set aside repudiated compromises. ${ }^{40}$ The following section proposes a decision rule for adjudicating repudiated compromises and describes the underlying rationale, drawn generally from economic theory, that justifies it.

\section{PRoposed Decision Rule}

The proposed decision rule applies to repudiated compromises that follow an actual or threatened breach, where the breach in question results from a change in the conditions under which performance will be rendered. There are two types of such changes, and the rule applies to both situations: (1) changes that render performance more difficult or costly than was anticipated at the time of contract (e.g., new materials must be used; the route of travel is longer) and (2) market changes that render performance with one's contractual partner less profitable than performance for another (e.g., new buyers are available and willing to pay more).

\footnotetext{
38. In Stilk the crew of sailors had lost two members.

39. In the Recker compromise, the buyers had agreed to a higher price for the sale of land.

40. It is important to distinguish the cases of repudiated compromise discussed supra from other cases in which the same doctrines are employed - e.g., duress, frustration, consideration, etc.- - but no compromise or second agreement is in dispute. Rather, only one, initial contract is at issue. It is quite possible that these doctrines satisfactorily resolve initial contracts but not repudiated compromises. That is, the repudiated compromise, because it is a more complicated contractual relation, may be unfit for resolution under doctrines designed to resolve more straightforward, initial contracts. For example, with the cases discussed supra, compare the following. On duress: Kaplan v. Kaplan, 25 Ill. 2d 181; 182 N.E.2d 706 (1962); Gates v. Shutts, 7 Mich. 126 (1859). On frustration: American Trading and Prod. Corp. v. Shell Int'I Marine Ltd., 453 F.2d 939 (2d Cir. 1972); Superintendent and Trustees of Public Schools v. Bennett, 27 N.J.L. 513 ( N.J. 1859). On release and waiver: Ricketts v. Pennsylvania R.R., 153 F.2d 757 (2d Cir. 1946); Goldbard v. Empire State Mut. Life Ins. Co., 5 A.D.2d 230, 171 N.Y.S.2d 194 (N.Y. App. Div. 1958).
} 


\section{A. A New Rule}

The proposed rule: The compromise is upheld if it is consistent with the risk allocation implied by or explicit in the original contract; if the compromise is not consistent with that allocation, then the compromise is set aside and the contract is upheld. For example, resolving the Stilk case (crew reduced in size is promised higher wage) turns critically on whether the risk of reduced crew size that resulted from desertion is allocated to the captain or to the crew, and whether the compromise (crew to be paid additional wages) is consistent with that allocation. If the compromise is consistent with the original allocation it is upheld, if not it is set aside. (We shall see later that the compromise was indeed consistent with the original allocation and should have been upheld.)

Two corollaries accompany this rule. The first is as follows: $A$ change in conditions which makes one party's performance more difficult, more costly, or less profitable is, by itself, insufficient justification for setting aside an original contract. Note that under this corollary, parties are held to their contractual obligation even in the face of unexpected changes in circumstance or changes in the market. Thus, there is no justification for upholding a compromise that merely compensates a party who has encountered difficulties or that alleviates the obligation when a party has found a preferable contractual partner.

The second corollary is that all risks of changed conditions-whether they affect performance, the market, or both-are allocated, implicitly or explicitly, to the parties. If the allocation is not implicit or explicit in the original contract, then the risk is allocated to the party who can most easily and cheaply control or predict the change in conditions or who can recoup losses arising from it through its future conduct. ${ }^{41}$ Put succinctly, it is the cheapest cost avoider who shoulders a particular risk. It follows from this that the burden of a risk must remain with the party who assumed it or to whom it was allocated, and may not be shifted to the other party (unless the other party agrees and is compensated). When this occurs-the burden shifts to the opposite party, who is compensated-it amounts to a rescission of the original contract and its replacement with another. Further, it follows that one party may not cause changed conditions, or other risks, to descend upon the other party. In so doing, one party could increase the other's burdens and costs of performance. (An example of this occurs in Angel v. Murray. ${ }^{42}$ )

In summary, the decision rule assumes that a contract cannot be compromised simply because one party encountered the very conditions for which it assumed, or was allocated, the risk. Thus, where there are changed conditions,

41. This suggests that parties to a contract should, in fact, explicitly allocate as many risks as they can reasonably foresee at the time of the original contract.

42. 113 R.I. 482,322 A.2d 630 (1974). 
a compromise that is made to preserve a party's risk burden is to be upheld.$^{43}$

\section{B. Justification for the Rule}

The aim of the rule is to enforce a stable allocation of risks once a contract has been made. ${ }^{44}$ The contract explicitly, or more often implicitly, allocates to each party the risk that one or more disadvantageous events may occur. Perhaps the principal risk that each party bears is the possibility that it may have made a bad deal: it may have underestimated its costs, wrongly predicted the weather, or erroneously concluded that it could not have made a better deal elsewhere if it had searched or waited longer. I do not undertake here to explain how such risks should be allocated (except to note that the more control a party has over a particular condition, the more likely it is to be allocated the risk that unfavorable changes in that condition will occur). Rather, my purpose is to show that only stable allocations of risk-more simply, stable contracts-are capable of achieving the ends for which contracts are designed. Only stable contracts facilitate advantageous exchanges of wealth; thus the compromise subsequent to a contract's formation must seek to preserve the original, contracted-for risk allocation, meanwhile adapting it to the changed conditions. Unstable or flexible contracts promote uncertainty and cannot achieve the ends for which contracts are designed. To see why this is so it is necessary to consider briefly why exchanges of wealth are desirable and why they are facilitated by stable contracts.

Exchanges of wealth are desirable because they facilitate the efficient allocation of resources. That is, when people buy, sell, and trade, goods or resources that are of less value to one party move to a party that places a higher value on them. Such exchanges are termed value-enhancing because, for example, when party $A$ gives up $X$, which he does not want, in order to obtain $Y$, which he does want, and if party $B$ in the exchange does the same thing, then the total value to the two parties has increased: each party has more value than he had before because he released the less desirable for the more desirable. ${ }^{45}$ Especially in cases where the seller sells for somewhat more than he

43. Note, however, that although the contract may not be set aside for changed conditions, breach is still possible under the first principle with payment of expectation damages to the breached-against party. That is, the breaching party need not specifically perform, but it must pay damages that will put its contractual partner in as good a position as it would have attained had performance been rendered. I do not consider further here the issues attending expectation damages: how they should be calculated, whether in fact they fully compensate, and what to do in cases involving unique goods. Rather, I assume for the present purposes that expectation damages can be conceived of in such a way that their payment fully satisfies the contractual obligation. The central point is that the rule will not allow changed conditions to justify setting aside a contract and upholding a compromise, but it will support breach with expectation damages as a method of upholding the contract.

44. A discussion of efficient risk allocation may be found in R. COOTER \& T. ULEN, LAW AND ECONOMICs 326-476 (1988) (Although their discussion is aimed at risks in tort, much of it is generally applicable to the allocation of risks under a contract).

45. A detailed elaboration appears in R. POSNER, ECONOMIC ANALYSIS OF LAW 3-17 (3d ed. 1986). 
would have taken, and the buyer buys for somewhat less than he would have paid, total value has increased because each party has gained somewhat more than he would have required to make the exchange.

Contracts facilitate these value-enhancing exchanges of wealth because contracts allow exchanges in which both parties need not perform simultaneously. Briefly put, contracts make otherwise inconvenient exchanges of wealth convenient. Each party may conduct itself as though the other will perform because it relies upon the contract to ensure that the other will indeed perform in the future ${ }^{46}$ or will pay damages in lieu of performance. Admittedly the latter option-payment of damages - is only successful in facilitating exchange if, in case of breach, the breached-against party is put in as good a position after breach as he would have been in after the other party's performance. That is, the breached-against party must receive expectation damages. Expectation damages are often difficult to obtain (courts are reluctant to award them, breachers reluctant to pay them), and even if obtainable are difficult to calculate. Whether expectation damages that are actually received do, in fact, put the breached-against party in as good a position as performance would have put him in is arguable and will not be discussed further here. At least theoretically, expectation damages put the breached-against party in as good a position, and thus contracts-even breached contracts-may act to facilitate exchanges of wealth in which the transfers made by the parties need not be simultaneous.

But only stable contracts (more properly stable risk allocations) may accomplish this. Unstable contracts-those defeated by unexpected changes in conditions-are of little value in providing the assurance of future performance or payment of damages. Hence unstable contracts are of little value in facilitating exchange. The decision rule proposed here, therefore, calls for a presumptively stable risk allocation in the face of changed conditions.

We may ask whether the rule is usefully different from the state of mind theory, for at least on the surface the two seem to espouse a common aim: to preserve what the parties were thinking about or had in mind when they came to the compromise. That is, the state of mind theory upholds compromises where the parties compromised voluntarily, ${ }^{47}$ and the proposed rule upholds the risks and costs that the parties allocated to each other and to themselves. Stated simply, both theories look to the parties' mental processes and how they viewed the compromise. The difference is that the state of mind theory employs only a single, subjective criterion-whether each party seems, in the eyes of the court, to have entered the compromise free of coercion-while the proposed rule looks to an allocation of risks. To give an example: Where a ship owner agrees to transport cargo from here to there, the rule allocates to him the risk

46. Professor Fried makes this point. See C. FRIED, CONTRACT AS PROMISE 9-11 (1981), although, somewhat oddly, he supports the renegotiation of contracts in the face of changed conditions, see id. at 3335.

47. See Hillman, supra note 12. 
that the ship will break down, the crew will get sick, and fuel supply will be too short. For it is the owner of the ship who is best able to predict and control the sea-worthiness of the ship, the working and living conditions of the crew, and the fuel supply. Moreover, the rule allocates these risks to the ship owner, whether he explicitly agreed to these or not, and even if he never had them in mind. Of course, if he actually had these and other risks in mind at the time of the contract, the rule would also allocate them to him. But he need not have thought of and explicitly assumed them, though his having done so will always be dispositive. ${ }^{48}$

The state of mind theory, by contrast, is wholly subjective and does not address the several, specific risks that may arise; it merely asserts that if the court believes the compromise was voluntary, it must be upheld.

\section{Where Conditions Have Not Changed}

The proposed rule applies to compromises made under changed conditions which motivated an actual or threatened breach. But where a compromise was entered into after a breach not motivated by any changed conditions, the compromise is always to be set aside and the original contract upheld. The reason is that, without a change in conditions, there is no new burden to be shouldered by a party, and so the original risk allocation is not in danger of being disturbed. This being so, no risk-preserving function can be served by a compromise. Indeed the usual function of such "compromises" is simply to "hold up" the other party and to secure for oneself a more advantageous outcome than that originally contracted for. Having its contractual partner in a position of reliance, the party "holds up" its partner, refusing to perform until additional consideration is put forth.

\section{APPLICATION OF THE PRINCIPLES}

The cases in this section fall roughly into four nonexclusive categories, and it will be seen that the decision rule applies across the range of cases presented: cases (1) in which the conditions affecting performance have changed, (2) in which the market conditions have changed, (3) in which compromises do maintain the original risk allocation, and (4) in which no change in conditions has occurred.

48. Of course, if such risks are explicitly allocated to the other party, that allocation must be honored. The point here is that the decision rule applies in the absence of explicit allocations to the contrary. 


\section{A. Cases of Changed Performance Conditions}

Two cases in which a breach resulted from changed conditions are Goebel (citing mild winter, ice company demands higher price from brewer whose beer will spoil) and Moore (manufacturer refuses to deliver engine until buyer releases it from liability for delay). Recall that the rule holds that changed conditions cannot, by themselves, justify a seller's breach. When changed conditions do occur, then, we must consider how this burden should be allocated. The rule mandates that the allocation should be consistent with the implicit or explicit risk allocations at time of contract.

For example, in Goebel, the original contract called for the brewer/buyer to pay for ice at $\$ 1.75$ per ton or $\$ 2.00$ per ton if the ice crop was short. Thus, it is clear that the risk of warm weather and a short ice crop was explicitly allocated to the buyer, but only to the extent of $\$ 2.00$ per ton, after which the burden of any remaining risk should have been allocated to the seller, who was the "harvester" of the ice, as it were, and in the best position to recoup any losses in the following year or years. Under the decision rule, then, the seller cannot shift the burden amounting to $\$ 3.50$ per ton to the buyer. Where the Goebel court assigned to the buyer the risk of a mild winter (by making the buyer pay $\$ 3.50$ per ton), the present theory would limit the buyer's risk allocation to that explicitly given in the contract and would require the buyer to pay $\$ 2.00$ per ton. The seller assumes the remaining risk.

With regard to Moore, the present theory allocates the risk of manufacturing delays (for the locomotive engine) to the manufacturer/seller, since it is in the best position to predict the time needed for manufacturing, to control the time expended in production, and to mitigate any delays that do occur, in short, it is the least cost avoider. Thus, the buyer's claim for damages resulting from the delay would be entertained and the waiver/compromise, to which the buyer was compelled to agree before seller would deliver, would be considered void. Contrast this to the court's result holding the waiver valid.

\section{B. Cases of Changed Market Conditions}

The cases of Roth Steel Products and Reynolds are examples in which market conditions, rather than the conditions under which performance would be rendered, have changed. In Roth Steel (seller ceases delivery until buyer pays the new, higher market price) the changed condition-caused by federal price controls, limited supply, and a favorable export market-was that the seller could more profitably sell to another buyer, provided his goods were released from the contractual obligation. Under the decision rule, this changed (market) condition is conceived of as a risk that, like other risks of changed conditions, was allocated to the parties at the time of contract: to the seller was allocated the risk that market prices may go up, to the buyer that they may go down. 
Each party undertakes the risk that later the market may be more advantageous; yet this risk is assumed in order to take advantage, now, of the benefit of a stable contract. (Stable contracts, as we have seen, allow nonsimultaneous exchanges of wealth.) That these assumed and allocated risks occasionally do obtain, as they did in Roth Steel, is not reason to set aside the contract. Under the decision rule, then, a market change that results in higher prices will not excuse a seller's breach; he must perform or pay the buyer expectation damages. The seller in Roth Steel, therefore, would be obligated to sell to the buyer at the contract price or to put the buyer in as good a position as he expected.

For Roth Steel, the decision rule confirms the court's holding but not its reasoning. The Roth Steel court based its holding on the seller's use of coercion, indicating in dicta contrary to the present theory that, had it not been for seller's use of coercion, the changed market conditions would have justified the seller's seeking a higher price.

Another case involving changed market conditions is Reynolds $v$. Nugent. Here the town paid the Civil War mercenary only $\$ 100$ (after he performed) and repudiated its promise to match the higher offer $(\$ 350)$ that had been made by another town. The court might have reached any of the following outcomes when, after the town breached its compromise, the mercenary sued:

(1) The town owes the mercenary $\$ 100$.

(2) The town owes the mercenary $\$ 350$.

(3) The town owes the mercenary about $\$ 250$.

The first outcome holds for specific performance under the original contract, the second upholds the compromise, and the third upholds the compromise with payment by the soldier of expectation damages to the town, assuming that the town could have enlisted another mercenary for about $\$ 100$. (Indeed, these damages may be greater, amounting to the pay of another mercenary plus search costs.) Under the doctrines of pre-existing duty and consideration, the court chose the first outcome. Under the present theory, also, the first outcome would be chosen. The decision rule indicates that the changed market condition encountered by the soldier (another buyer willing to pay more) is insufficient to set aside the soldier's contractual obligation. With the risk of changed conditions allocated to the parties, it must be the soldier in this case who assumed the risk that at some later point, as happened here, a preferable contractual partner might be found. ${ }^{49}$

49. I use the Reynolds case as an example of changed market conditions, and I argue that changed conditions will not void a contract. I do not address here, however, a possible exception to the rule, that specific performance may not be required in a personal service contract such as the one in Reynolds. Moreover, the facts reported in Reynolds are unclear as to whether the agreement was struck at the time 


\section{Burden-Preserving Compromises}

In requiring a stable allocation of risks, the decision rule assumes not only that changed conditions cannot defeat a contract but also that a party may not shift to his contractual partner a burden which was originally allocated to the party himself. Moreover, a party may not itself cause disadvantageous changed conditions to descend upon its partner. An example of the potential shifting of an allocated risk burden occurs in Angel v. Murray (refuse hauler receives additional payment because of increase in number of housing units).

In Angel, the change in conditions that justified the refuse hauler's increased payment was roughly a twenty-fold increase in new housing units over the number on which the contract was predicated. Here the city itself caused the burden of changed conditions to descend upon the refuse hauler, for the city controlled the number of housing units that would be built. It is not only that, at time of contract, the risk of a twenty-fold increase in new housing was implicitly allocated to the city (which was in the best position to control or predict this), but also that the city itself caused this risk to materialize. The decision rule does not bind a party to a contract that has been made more difficult or costly by the other party or by changed conditions caused by the other party. Rather, when one party causes changed conditions which will disadvantage its contractual partner, the party is, in effect, calling for additional services not bargained for at the time of contract. In such a case, the parties are free to reach a compromise, as they did in Angel. There is no reason to void the compromise, then, under the decision rule, for the compromise, which required the city to pay more, seeks to keep the burden of increased housing with the city. Under the present theory, then, the compromise would be upheld, as it was by the court in this case.

Another example of a compromise that seeks to maintain the initial risk allocation occurs in Stilk v. Myrick. Here the crew of a ship was reduced in size by two desertions, and the captain promised additional wages to those remaining. The implicit question, since the captain later repudiated this compromise, is where the burden of potential desertions should be located-in the crew or in the captain/employer. The answer is that the risk of reduced crew size should lie with the employer because he is in the best position to control and predict this possibility. It is the employer who selects the sailors and presumably exercises judgment in assessing their reliability. (If the crew were, say, unionized and hired as a group, then we might argue that the risk of desertion was allocated to the crew.) Further, the employer is in the best position to provide incentives for the sailors' continued reliability by making good on promises regarding food, working conditions, and so on. In Stilk, then, the compromise

of mustering in or earlier. Thus, the proposed rule as I have applied it in Reynolds is meant to be exemplary and not dispositive in this case. 
agreement of the higher wage should be upheld because it maintains this risk allocation: the employer bears the burden of reduced crew. This outcome is contrary to the court's holding in this case.

\section{Cases Without Changed Conditions}

The prototypical example of repudiated compromise after breach is the socalled hold-up problem seen in Alaska Packers Association v. Domenico (crew refuses to complete fishing expedition until employer doubles wage). The modern parallels are Austin Instrument (seller threatens breach unless desperate buyer agrees to prices above contract price) and Recker v. Gustafson, where the sellers of real estate extracted in compromise a second, higher price from the buyers.

In all three cases the party threatening breach did not claim changed conditions as a justification for the higher wage or price. And indeed on the facts reported there were no changed conditions. Thus, the original contract would be upheld. The rationale, as discussed above, is the necessity of stable contracts to exchanges that are not simultaneous. Like the courts in Alaska Packers and Austin Instrument, the present theory calls for upholding the original contract. Similarly in Recker the contract should be upheld, because there were no changed conditions affecting the sale of the property. This contradicts the actual outcome at trial but is consistent with the holding on appeal.

\section{CONCLUSION}

The repudiated compromise after breach presents courts with cases that strain traditional contract doctrine because, in contrast to the simple breach of contract, the parties have made two agreements governing the same transaction, and each party repudiates one of them. I have argued here that, in resolving such cases, courts should look to the changed conditions that gave rise to the breach and compromise and determine with which party the risk of such changed conditions should lie. Where the breach and compromise appear unmotivated by or independent of any changed conditions, courts should uphold the original contract.

The conception of contract that drives the decision rule proposed here disavows flexibility as a desirable trait of contract law. ${ }^{50}$ Indeed an explicit assumption has been that changed conditions will not give rise to a justified

50. This view diverges from at least one alternative proposal for resolving cases of this type, that of Professor Narasimhan, who stated explicitly that "contracting parties must have some flexibility to adjust the terms of their relationship to changing conditions." Elsewhere she writes generally of "the parties' need for flexibility." This assumption puts parties in an uncertain position. The degree to which their contractual partner is bound is limited by the probability that conditions unfavorable to the partner will arise. Thus, the certainty with which one may rely on the contract is limited by the foreseeability of changed conditions which the partner may encounter. See Narasimhan, supra note 12, at 62 . 
breach, except that breach with expectation damages may be permitted. The ideal contract and contract law espoused here, then, is one that stably allocates risks at the time of the original contract, and this allocation determines the rights and conduct of the parties should changed conditions arise. Contracts do not and should not require renegotiation whenever there are changed conditions; rather, they should continue to govern conduct over a variety of uncertain futures. 
